\title{
Diagnostics of Epistomatal Wax of Californian Pine Needles, and Their Association with Ozone-Caused Chlorotic Mottle
}

\author{
Satu Huttunen ${ }^{*}$, Andrzej Bytnerowicz ${ }^{2}$, Michael J. Arbaugh ${ }^{2}$, Katriina Bent ${ }^{1}$, \\ Marketta Karhu' ${ }^{3}$, Päivi Tuohimaa ${ }^{1}$ \\ ${ }^{1}$ Department of Biology, University of Oulu, Oulu, Finland \\ ${ }^{2}$ USDA, Forest Service, Pacific Southwest Research Station, Riverside, USA \\ ${ }^{3}$ Environment Office of Oulu, Oulu, Finland \\ Email: ${ }^{*}$ satu.huttunen@oulu.fi
}

Received 17 March 2014; revised 16 April 2014; accepted 3 May 2014

Copyright (C) 2014 by authors and Scientific Research Publishing Inc.

This work is licensed under the Creative Commons Attribution International License (CC BY). http://creativecommons.org/licenses/by/4.0/

(c) (i) Open Access

\begin{abstract}
Tropospheric ozone is a worldwide phenomenon causing injuries to forest trees. Californian ponderosa and Jeffrey pines are well known for their sensitivity to ozone, while other pine species have varied in their susceptibility. Sensitive pine species are known for their chlorotic mottle and tip burn symptoms, caused by ozone air pollution. Epistomatal wax plugs and filamentous waxes around stomata are typical for pine needle surfaces. In this study, we investigated epistomatal and epicuticular needle waxes in eight species of field-grown pines in 1985, 1986 and 2006. The epistomatal wax plugs were present in asymptomatic needles without chlorotic mottle ( $23 \%$ of needles). A lack of wax plugs in needles with chlorotic mottle and tip burn symptoms was common $(76 \%$ of needles). More abundant existence of mottling associated with stomata without wax plugs in twoyear-old needles, compared with one-year-old needles $(43 \%$ and $33 \%$, respectively), indicated chronic injury development over time.
\end{abstract}

\section{Keywords}

Pinus coulteri, P. jeffreyi, P. ponderosa, Epistomatal Wax Plugs, Scanning Microscopy (SEM)

\footnotetext{
${ }^{*}$ Corresponding author.
}

How to cite this paper: Huttunen, S., et al. (2014) Diagnostics of Epistomatal Wax of Californian Pine Needles, and Their Association with Ozone-Caused Chlorotic Mottle. American Journal of Plant Sciences, 5, 1733-1744. 


\section{Introduction}

Ozone $\left(\mathrm{O}_{3}\right)$ injuries in montane coniferous forests in California have been recorded since the1950's [1] [2]. Diagnostic injuries of oxidant and winter fleck on Western pine needles were first recognized in the 1970's [3]. The most $\mathrm{O}_{3}$ sensitive Western pines are $P$. coulteri D. Don (Coulter pine), $P$. jeffreyi Balf (Jeffrey pine), $P$. lambertiana Douglas (sugar pine), and $P$. ponderosa (ponderosa pine) [4]. Experimental results during different seasons revealed $\mathrm{O}_{3}$ sensitivity to vary with exposure time, with the order of species sensitivity being: $P$. ponderosa, $P$. jeffreyi, $P$. coulteri, then $P$. lambertiana. Ozone injuries of the most sensitive pine species were associated with epidermal and hypodermal thickness, while in more tolerant species the injuries were found especially in substomatal mesophyll cells [5]-[7].

Stomata regulate the flow of gases in and out of leaves [8]. The stomata of many gymnosperms [9] and a few angiosperms appear to be partially blocked by filamentous waxes [10]. In the genus Pinus, the stomatal Florin ring and the stomata lantechamber [11] are covered with tubular epicuticular waxes, and this structural wax distribution reaches surrounding areas in the stomatal rows. These waxy plugs occlude the entrance of stomata, particularly in conifers [12] [13]. Stomatal waxes may inhibit the ingress of liquid water into the intercellular air spaces. On the other hand, the presence of large amounts of wax covering stoma affects the rate of leaf gas exchange by decreasing the area available for diffusion. Stomatal wax plugs and imbricacy have been shown to reduce maximum leaf conductance in conifers [13] [14]. However, the role of the stomatal antechamber wax plugs is not clear when air pollution is considered.

Changes in conifer needle epicuticular waxes, and especially epistomatal waxes, have been used as an early diagnostic tool in needle injuries [15] [16]. Experimental responses with different pollutants and case studies around mixed pollution sources indicate changes in epicuticular waxes especially at the top of and around the stomata. The observations vary due to species, environment, needle ontogeny, age and longevity [15] [17] [18].

In conifers, drought resistant features such as a general reduction in physiological activity in periods of drought, sunken stomata and thick dense cuticles are typical. Chronic $\mathrm{O}_{3}$ injury in Californian pine species is related to increased $\mathrm{O}_{3}$ uptake due to sluggishness of stomata and their partial opening at night [19] [20]. However, functional injury has not been directly connected with diagnostics e.g. chlorotic mottle symptoms, condition of epicuticular waxes, and existence of wax plugs. Chlorotic mottle is a visible needle injury symptom developing in Californian pines in the field.

The specific type of chlorotic mottling in ponderosa pine and $\mathrm{O}_{3}$ needle mottle in seen in other pine species are one and the same disease [21]. Seasonal advancement of mottling, or the rate at which needles are injured by ozone, has been found to vary both between and within the different pine species. While some $\mathrm{O}_{3}$-exposed trees may retain only current-year needles, others may show retention of affected needles for two, three or four seasons [21].

We studied epistomatal wax plugs and injury of epicuticular waxes of needles in several California pine species in situ. Our aim was to develop $\mathrm{O}_{3}$ impact diagnostics using the condition of epicuticular wax and occurrence of wax plugs in needles of these selected pine species. Our hypothesis was that a lack of stomatal antechamber wax plugs and visible chlorotic mottle symptoms are connected, and that diagnostic differences between needle-age classes can be found. One aim was to find a species-specific early diagnostic tool that would combine microscopic injuries with visible chronic $\mathrm{O}_{3}$ symptoms in situ. Repeated monitoring was used to assess annual variation in the condition of trees.

\section{Material and Methods}

\subsection{Sites}

The individual test trees were selected during the first sampling year in the San Bernardino Mountains and in the Riverside Botanic Gardens of southern California. Field samples were collected three times from the same trees, in 1985, 1986, and 2006. Needle sampling sites were located at forest sites with altitudes varying between 335 $2800 \mathrm{~m}$ asl (Table 1 ).

Needle samples were taken from the bottom, westerly side of adult native trees ( $>2 \mathrm{~m}$ above ground). We used small or large open stands and dominant or co-dominant single trees for needle collection. Sampling took place in March 1985, 1986, and again in April 2006. Marked Pinus species were Pinus albicaulis Engelm., alpine white bark pine (not found in 2006); Pinus attenuata Lemmon, knob cone pine (not found in 2006); Pinus coulteri, 
Table 1. Needle samples at field sites in Riverside and the San Bernardino Mountains, altitude and pine species collected in 1985, 1986 and 2006.

\begin{tabular}{|c|c|c|}
\hline Site and sample number & Altitude (m asl) Latitude N, W & Species \\
\hline 0) Botanic Gardens Riverside (1 - 6), single tree & $\begin{array}{c}335 \text { - } 442 \mathrm{~m} \\
33^{\circ} 58 ' 10.71^{\prime \prime N}, 117^{\circ} 19^{\prime} 9.77^{\prime \prime} \mathrm{W}\end{array}$ & $\begin{array}{c}\text { Pinus attenuata }{ }^{*} \\
\text { P. coulteri, } P \text {. muricata }\end{array}$ \\
\hline 1) Thurman Flats $(7,8)$, small open stand, dominant tree & $\begin{array}{c}1200 \mathrm{~m} \\
34^{\circ} 5^{\prime} 51.02^{\prime \prime} \mathrm{N}, 116^{\circ} 57^{\prime} 44.56^{\prime \prime} \mathrm{W}\end{array}$ & Pinus coulteri \\
\hline 2) Highway $38(9,10)$, small open stand, dominant tree & $\begin{array}{c}1250 \mathrm{~m} \\
34^{\circ} 5^{\prime} 55.27^{\prime \prime} \mathrm{N}, 116^{\circ} 58 ' 25.21^{\prime \prime W}\end{array}$ & Pinus ponderosa \\
\hline 3) Highway $38(11,12)$, small open stand, dominant tree & $\begin{array}{c}1800 \mathrm{~m} \\
37^{\circ} 7^{\prime} 28.84^{\prime \prime} \mathrm{N}, 116^{\circ} 59^{\prime} 10.23^{\prime \prime W}\end{array}$ & Pinus coulteri \\
\hline 4) Highway 38 (13, 14 14a, 14b), small open stand, co-dominant tree & $\begin{array}{c}1900 \mathrm{~m} \\
34^{\circ} 8{ }^{\prime} 7.15^{\prime \prime} \mathrm{N}, 116^{\circ} 59^{\prime} 12.11^{\prime \prime W}\end{array}$ & $\begin{array}{l}\text { Pinus coulteri, } \\
\text { P. ponderosa }\end{array}$ \\
\hline $\begin{array}{l}\text { 5) Highway } 38 \text { (15 - 20) small open stand, co-dominant tree 15, 16; } \\
\text { individual trees mixed with more numerous ponderosas 17, 18; } \\
\text { individual tree near highway 19, } 20\end{array}$ & $\begin{array}{c}2000 \mathrm{~m} \\
34^{\circ} 9^{\prime} 22.21^{\prime \prime} \mathrm{N}, 116^{\circ} 57^{\prime} 45.55^{\prime \prime W}\end{array}$ & $\begin{array}{l}\text { Pinus albicaulis }{ }^{* *} \text {, } \\
\text { P. coulteri, } \\
\text { P. ponderosa }\end{array}$ \\
\hline 6) Highway $38(21,22)$, large open stand, co-dominant tree & $\begin{array}{c}2000 \mathrm{~m} \\
34^{\circ} 10^{\prime} 4.00^{\prime \prime} \mathrm{N}, 116^{\circ} 54^{\prime} 18.40^{\prime \prime} \mathrm{W}\end{array}$ & Pinus ponderosa \\
\hline 7) Barton Flats, $(23,24)$, large open stand, co-dominant tree & $\begin{array}{c}2000 \mathrm{~m} \\
34^{\circ} 10^{\prime} 33.42^{\prime \prime} \mathrm{N}, 116^{\circ} 52^{\prime} 4.60^{\prime \prime} \mathrm{W}\end{array}$ & Pinus ponderosa \\
\hline 8) Onyx Summit $(25,26)$, large open stand, co-dominant tree & $\begin{array}{c}2800 \mathrm{~m} \\
34^{\circ} 11^{\prime} 18.90^{\prime \prime} \mathrm{N}, 116^{\circ} 42^{\prime} 41.88^{\prime \prime W}\end{array}$ & Pinus jeffreyi \\
\hline 9) Highway $38(27,28)$, sparesely located trees & $\begin{array}{c}2650 \mathrm{~m} \\
34^{\circ} 12^{\prime} 55.06^{\prime \prime} \mathrm{N}, 116^{\circ} 44^{\prime} 25.15^{\prime \prime} \mathrm{W}\end{array}$ & Pinus monophylla \\
\hline 10) Highway 18 (29, 30), sparsely located trees & $\begin{array}{c}2000 \mathrm{~m} \\
34^{\circ} 18^{\prime} 57.99^{\prime \prime} \mathrm{N}, 116^{\circ} 49^{\prime} 32.84^{\prime \prime W}\end{array}$ & Pinus monophylla \\
\hline
\end{tabular}

*Tree has died, no samples in 2006; ${ }^{* *}$ P. lambertiana samples in 2006.

D. Don, Coulter pine; Pinus jeffreyi Balf, Jeffrey pine; Pinus lambertiana Douglas, sugar pine (only 2006); Pinus monophylla Torr. \& Frem., single-leaf pinyon; Pinus muricata D. Don, bishop pine (not found in 2006); and Pinus ponderosa Douglas ex Lawson \& C. Lawson var. ponderosa, ponderosa pine [22] [23]. Typical morphological characteristics of these pines are presented in Table 2. The one- and two-year-old needles were separated and studied independently. In some samples, three-year-old needles were also available. The needles were gently air dried at room temperature and placed in protective parcels, then air mailed to the University of Oulu where visible needle injuries (mottling and tip burn) were detected by MBC-stereomicroscope.

\subsection{Scanning Electron Microscopy (SEM)}

The air dried or/and freeze-dried portions of needles were cut from their middle part (pieces about $0.5 \mathrm{~cm}$ ), placed on brass stubs and sputtered with 25 - $30 \mathrm{~nm}$ gold-palladium (POLARON 5100). The samples were studied with JEOL JSM-35 Scanning electron microscope (SEM) with $15 \mathrm{kV}$. In 2006, samples were sputtered for 30 sec with $30 \mathrm{~nm}$ palladium and studied with JEOL JSM-6400. The samples were micrographed in a standardized series under the microscope, where the field of view of selected mid-needle surface area $\left(0.061 \mathrm{~mm}^{2}\right)$ was scored with $100 \times-200 \times$, and $400 \times$ magnifications, and epistomatal wax plugs with $1000 \times$ or $2000 \times$ magnifications. In some cases, wax fibrils were further micrographed at magnification of 10,000×. The condition of the waxes in $2-4$ stomatal rows in the middle of the adaxial side of each needle were assessed in random order. Ten stomata (wax plugs and filamentous waxes) were classified under the SEM and notes of special features were listed as follows: (+++ very abundant, ++ moderately abundant, + exist to some extent, $(+)$ exist to a minor extent, - not observed) for the following characteristics: 
Table 2. Typical morphological features of the pine species studied.

\begin{tabular}{|c|c|c|}
\hline Pine species & $\begin{array}{l}\text { Number of needles in a fascicle and number of stomatal rows, } \\
\text { mean of } 20 \text { needles in this study }\end{array}$ & $\begin{array}{l}\text { Typical length of needles and their longevity; } \\
\text { mean length of } 20 \text { needles in this study }\end{array}$ \\
\hline P. albicaulis & 5 & $3-7 \mathrm{~cm}, 5-8$ yrs \\
\hline White bark pine & 9.3 & $4.78 \mathrm{~cm}$ \\
\hline P. attenuata & 3 & $9-15 \mathrm{~cm}, 4-5 \mathrm{yrs}$ \\
\hline Knob cone pine & 24.4 & $12.21 \mathrm{~cm}$ \\
\hline P. coulteri & 3 & $16-30 \mathrm{~cm}, 3-4 \mathrm{yrs}$ \\
\hline Coulter pine & 22.5 & $19.55 \mathrm{~cm}$ \\
\hline P. jeffreyi & 3 & $12-15 \mathrm{~cm}, 4-6 \mathrm{yrs}$ \\
\hline Jeffrey pine & 16.00 & $9.76 \mathrm{~cm}$ \\
\hline P. monophylla & 1 & $3-6 \mathrm{~cm}, 4-12$ yrs \\
\hline Single leaf pinyon & 25.8 & $3.75 \mathrm{~cm}$ \\
\hline P. muricata & 2 & $7-15 \mathrm{~cm}, 2-3$ yrs \\
\hline Bishop pine & 12.4 & $9.33 \mathrm{~cm}$ \\
\hline P. ponderosa & 3 & $17-25 \mathrm{~cm}, 4-6$ yrs \\
\hline Ponderosa pine & 18.7 & $15.30 \mathrm{~cm}$ \\
\hline P. lambertiana & 5 & $6-11 \mathrm{~cm}, 2-4 \mathrm{yrs}$ \\
\hline Sugar pine & ? & ? \\
\hline
\end{tabular}

Resource: Richardson, D.M. (1998) Ecology and Biogeography of Pinus. Cambridge University Press, 527 p [40].

1) Erosion of epistomatal tubular wax.

2) Crumbly epistomatal wax.

3) Stomatal wax breaks.

4) Stomatal blockage with small particles.

5) Stomata with wax plugs.

6) Stomata without wax plugs.

\subsection{Diagnostics}

Observations were carried out of visible and epicuticular injury symptoms by three people, and scores of their observations averaged. In order to keep the microscopic work feasible, one individual adult indicator tree of each species per site was selected for study. Needle morphology and number of stomata varies greatly between pine species, which is indicated by the number of stomata rows (Table 2). The specific aim of this SEM study was to evaluate specific $\mathrm{O}_{3}$ symptoms of adult pine species. Work with adult trees is essential, since the limited time of the experimental work on $\mathrm{O}_{3}$ effects on seedlings is often insufficient to induce symptoms with. Developing field diagnostics of species-specific $\mathrm{O}_{3}$ symptoms is important, as the traditional biomonitoring tools for other air pollutants, such as their accumulation in plant tissues, cannot be used. The images of typical injury symptoms obtained with SEM were saved as paper micrographs. The total numbers of diagnostic-type figures saved, is 147 for samples collected in 1985-1986, and 83 in 2006.

\section{Results and Discussion}

Our study included pine individuals at typical sites with chronic $\mathrm{O}_{3}$ pollution. Due to abundance of chlorotic mottling in trees sampled in 1985 and 1986, there were only 13 needle samples without mottling symptoms (Table 3).

\subsection{Riverside Botanic Garden}

We evaluated three sample trees in the Botanic Garden (Figures 1(A)-(D), Table 4).

For Pinus attenuata, Whang et al. [24] characterize epicuticular needle waxes to be well developed. In 1985 and 1986 the needles collected had $8 \mathrm{~mm}$ tip burn and chlorotic mottle symptoms. The cuticular surface was classified to have eroded waxes but otherwise was healthy. By the 2006 sampling, the P. attenuata tree had died. 
Table 3. The visible mottling symptoms under stereomicroscope in needle samples (three samples were omitted due to fungal infection/and or mold problems).

\begin{tabular}{|c|c|c|c|}
\hline Samples & Mottling + tip burn two-year-old & Mottling + tip burn one year old & No symptoms \\
\hline \multirow{2}{*}{$1985+1986, n=60(57)$} & $n=25 / 57$ & $n=19 / 57$ & $n=13 / 57$ \\
\hline & $43.1 \%$ & $33.3 \%$ & $22.8 \%$ \\
\hline \multirow[t]{2}{*}{ 2006, $n=26$} & $n=12 / 26$ & $n=11 / 26$ & $n=3 / 26$ \\
\hline & $46.2 \%$ & $42.3 \%$ & $11.5 \%$ \\
\hline
\end{tabular}
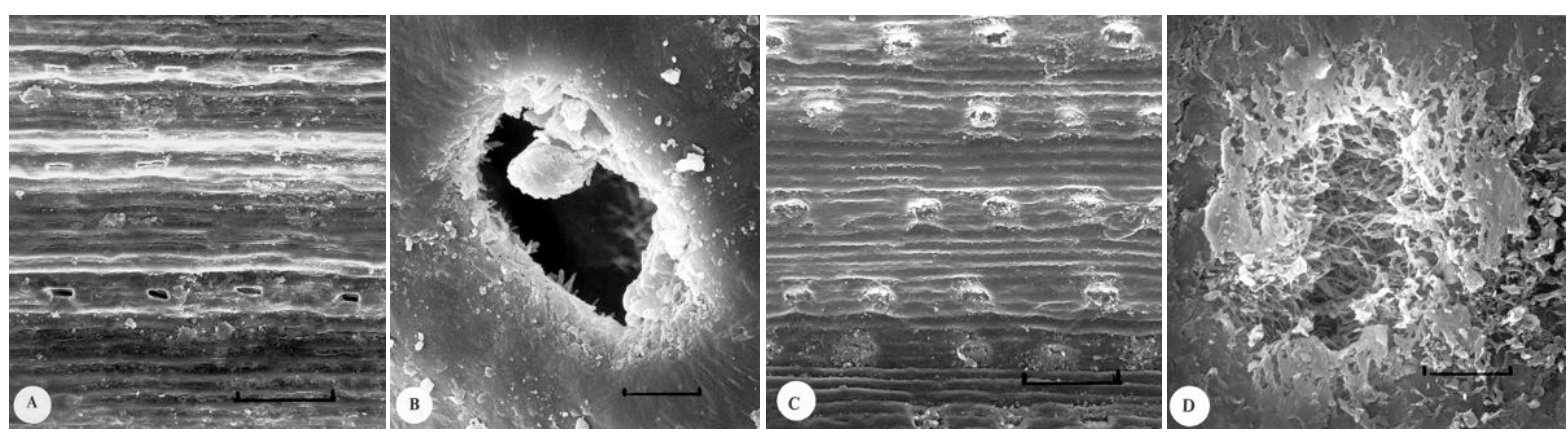

Figure 1. Pinus muricata ((A), (B)) epicuticular waxes and stomata without wax plug and $P$. attenuata ((C), (D)) eroded waxes and stomatal plugs. Riverside Botanic Gardens 1985, 1986. Bars (A) and (C) $=10 \mu \mathrm{m},(B)$ and (D) $=1 \mu \mathrm{m}$.

For P. muricata, Whang et al. [24] characterize features of the outer cuticular surface to be weakly developed. The young needles of $P$. muricata tree in the first two samplings were classified as visibly healthy, but needle epicuticular waxes were in poor condition, and the whole epistomatal wax structure was destroyed (Figure 1(A), Figure 1(B)). All micrographed stomata were empty, and stomatal plugs were lacking. By 2006, the tree had died.

For $P$. coulter, Whang et al. [24] consider the epicuticular wax surface to be well developed and stomatal wax plugs present. In the sample from the present study, $P$. coulter had visibly healthy young needles, however slight mottling was observed under light microscope in the two-year-old needles. In 2006 only the P. coulteri from all the marked test trees was still alive at the Botanical Garden, it exhibited slight microscopic injuries, but did not show visible injuries (Figure 2, Table 4).

\subsection{San Bernardino Mountains}

\subsubsection{5 and 1986}

Coulter pines in the San Bernardino Mountains had chlorotic mottling and tip burn symptoms in all needle age classes (1-year-old, 2-year-old, 3-year-old), and the epistomatal cuticular waxes were damaged. These results were similar to those found in 1985 and 1986 (Figure 2, Table 4).

Pinus albicaulis (white bark pine). Whang et al. [24] consider its cuticular wax surface to be well developed and stomatal plugs to be absent. In our sample tree, the needles were extremely xeromorphic with thick, ridged epicuticular waxes. Stomata were located in deep grooves. In many needle samples, the thick wax surface was broken into wax plates and cuticular injury diagnostics and comparison with other species was not possible. However, the stomatal wax plugs were present in young needles (Figure 3(A), Figure 3(B), Table 4).

$P$. jeffreyi. Most needles indicated epicuticular wax changes. The tube-like waxes were observable only in stomatal plugs of current year needles. The sample tree was growing at an altitude of $2800 \mathrm{~m}$ (Figure 4, Table 4).

P. ponderosa. The needles revealed chlorotic mottling and tip burn symptoms with intensive erosion of epicuticular waxes, and additionally some fungal infection. In samples with lower fungal infection, the differences in the wax quality between the needle years were observable. The waxes were classified to be in better condition in the eastern parts of the San Bernardino Mountains than in sites closer to the Los Angeles Basin and in Riverside. In young needles, stomatal wax plugs were abundantly present, but in older mottled needles they were absent in $52 \%$ of the documented samples. In many, cases some stomata poseessed plugs while some were without, depending on the stage of chlorotic mottling and tip burn of needles (Figure 5, Table 4). 
Table 4. Species-specific diagnostic epicuticular wax symptoms and wax plug coverage of one/two-year-old needles. Abundance,,$++++++(+)$; not observed -, n.d = not detected, combination of observations in 1985 and 1986.

\begin{tabular}{|c|c|c|c|c|c|c|}
\hline \multicolumn{7}{|c|}{$\begin{array}{c}\text { Pinus albicaulis symptoms of one/two-year-old needles, combination of observations in } 1985 \text { and } 1986 . \\
\text { Visible symptoms: Mottling, no clear mottling in young needles } 1985 .\end{array}$} \\
\hline Site number 5 & $\begin{array}{l}\text { Erosion of } \\
\text { epistomatal wax }\end{array}$ & $\begin{array}{l}\text { Crumbly } \\
\text { epistomatal wax }\end{array}$ & $\begin{array}{l}\text { Breaks of } \\
\text { epistomatal wax }\end{array}$ & $\begin{array}{l}\text { Particle blockage } \\
\text { of stomata }\end{array}$ & With wax plugs & Without wax plugs \\
\hline & $++/$ n.d & $-/$ n.d & -/n.d. & $+/$ n.d. & $+/$ n.d. & -/n.d. \\
\hline
\end{tabular}

Pinus attenuata wax symptoms of one/two-year-old needles: Visible tip burn, mottling in 1985 two-year-old, no visible symptoms in 1986 needles. Figure 1(C), Figure 1(D)

\begin{tabular}{|c|c|c|c|c|c|c|}
\hline $\begin{array}{c}\text { Riverside } \\
\text { botanic gardens }\end{array}$ & $\begin{array}{c}\text { Erosion of } \\
\text { epistomatal wax }\end{array}$ & $\begin{array}{c}\text { Crumbly } \\
\text { epistomatal wax }\end{array}$ & $\begin{array}{c}\text { Breaks of } \\
\text { epistomatal wax }\end{array}$ & $\begin{array}{c}\text { Particle blockage } \\
\text { of stomata }\end{array}$ & With wax plugs & Without wax plugs \\
\hline & $++/++(+) \mathrm{M}$ & $+/++\mathrm{M}$ & $-/+\mathrm{M}$ & $+(+) /++\mathrm{M}$ & $-/ ?^{*} \mathrm{M}$ & $+++/$ ?*M \\
\hline
\end{tabular}

Pinus coulteri symptoms of one/two-year-old needles combination of observations in 1985 and 1986. Visible symptoms: Mottling, tip burn.

\begin{tabular}{|c|c|c|c|c|c|c|}
\hline Site number & $\begin{array}{c}\text { Erosion of } \\
\text { epistomatal waxes }\end{array}$ & $\begin{array}{c}\text { Crumbly } \\
\text { epistomatal wax }\end{array}$ & $\begin{array}{c}\text { Breaks of } \\
\text { epistomatal wax }\end{array}$ & $\begin{array}{l}\text { Particle blockage } \\
\text { of stomata }\end{array}$ & With wax plugs & Without wax plugs \\
\hline Botanic gardens & $+/++$ & $-/++$ & $(+) /-$ & $(+) /+(+)$ & $+++/-$ & $-/(+)$ \\
\hline 1 & $++/++$ & $++($ fungi $) /++$ & $++/+++$ & $(+) /(+)$ & $-1-$ & $-1-$ \\
\hline 2 & ?/++ & $(+) /(+)$ & $(+) /-$ & ?/++ & $? /-$ & ?/- \\
\hline 3 & $++/++$ & $+/++$ & $+/+++$ & $++/-$ & $? /+++$ & ?/+ \\
\hline 4 & $+/++$ & $+/+++$ & $+++/+++$ & $++/++$ & $+/+$ & $? / ?$ \\
\hline 5 & $+++/$ n.d & n.d. & n.d. & n.d & $(+) /(+)$ & $+/+++$ \\
\hline
\end{tabular}

Pinus jeffreyi symptoms of one/two-year-old needles combination of observations in 1985 and 1986. Visible symptoms: Mottling, chlorosis, tip burn.

\begin{tabular}{cccccc}
\hline Onys summit & $\begin{array}{c}\text { Erosion of } \\
\text { epistomatal wax }\end{array}$ & $\begin{array}{c}\text { Crumbly } \\
\text { epistomatal wax }\end{array}$ & $\begin{array}{c}\text { Breaks of } \\
\text { epistomatal wax }\end{array}$ & $\begin{array}{c}\text { Particle blockage } \\
\text { of stomata }\end{array}$ & With wax plugs \\
& $++(+) /+++$ & $-/(+)$ & $(+) /(+)$ & $-/-$ & $+(+)$ \\
\hline
\end{tabular}

Pinus monophylla symptoms of one/two-year-old needles combination of observations in 1985 and 1986 . No visible symptoms.

\begin{tabular}{cccccc}
\hline Site & $\begin{array}{c}\text { Erosion of } \\
\text { epistomatal wax }\end{array}$ & $\begin{array}{c}\text { Crumbly } \\
\text { epistomatal wax }\end{array}$ & $\begin{array}{c}\text { Breaks of } \\
\text { epistomatal wax }\end{array}$ & $\begin{array}{c}\text { Particle blockage } \\
\text { of stomata }\end{array}$ & With wax plugs \\
Site 9 & $+++/+++$ & $-/++$ & $-/+$ & $+/++$ & $-/+$ \\
10 & $+(+) /$ no sample & $-/$ & $-/$ & $+/+$ \\
\hline
\end{tabular}

Pinus muricata symptoms of one/two-year-old needles combination of observations in 1985 and 1986. Visible symptoms: Slight mottling in two-year-old, tip burn.

\begin{tabular}{|c|c|c|c|c|c|c|}
\hline $\begin{array}{c}\text { Riverside } \\
\text { botanic gardens }\end{array}$ & $\begin{array}{c}\text { Erosion of } \\
\text { epistomatal wax }\end{array}$ & $\begin{array}{c}\text { Crumbly } \\
\text { epistomatal wax }\end{array}$ & $\begin{array}{c}\text { Breaks of } \\
\text { epistomatal wax }\end{array}$ & $\begin{array}{c}\text { Particle blockage } \\
\text { of stomata }\end{array}$ & With wax plugs & Without wax plugs \\
\hline & $+++/+++$ & $++/++$ & $-1-$ & $(+) /-$ & $-1-$ & $+++/+++$ \\
\hline
\end{tabular}

Pinus ponderosa symptoms of one/two-year-old needles (abundance,,$++++++(+)$; not found -) combination of observations in 1985 and 1986. Mottling. Tip burn, except site 5 young needles in 1985.

\begin{tabular}{cccccc}
\hline Site number & $\begin{array}{c}\text { Erosion of } \\
\text { epistomatal Wax }\end{array}$ & $\begin{array}{c}\text { Crumbly } \\
\text { epistomatal Waxes epistomatal waxes }\end{array}$ & $\begin{array}{c}\text { Breaks of } \\
\text { of stomata }\end{array}$ & With wax plugs & Without wax plugs \\
2 & n.d. & n.d & n.d. & n.d & n.d. \\
\hline
\end{tabular}




\section{Continued}

\begin{tabular}{|c|c|c|c|c|c|c|}
\hline 4 & $++/+$ & $-/(+)$ & $-/+$ & $-/(+)$ & $(+) /-$ & $-1-$ \\
\hline 5 & $+++/+++$ & $-1-$ & $++/++$ & $-1-$ & $+/-$ & $++/(+)$ \\
\hline 6 & $++/+++$ & $-1-$ & $+/+$ & $-1+$ & $-1-$ & $(+) /+$ \\
\hline 7 & $+/+++$ & $-1-$ & $(+) /+$ & $-1-$ & $-1-$ & $-1++$ \\
\hline
\end{tabular}

?* observations not confirmed, $\mathrm{M}=$ mottling.
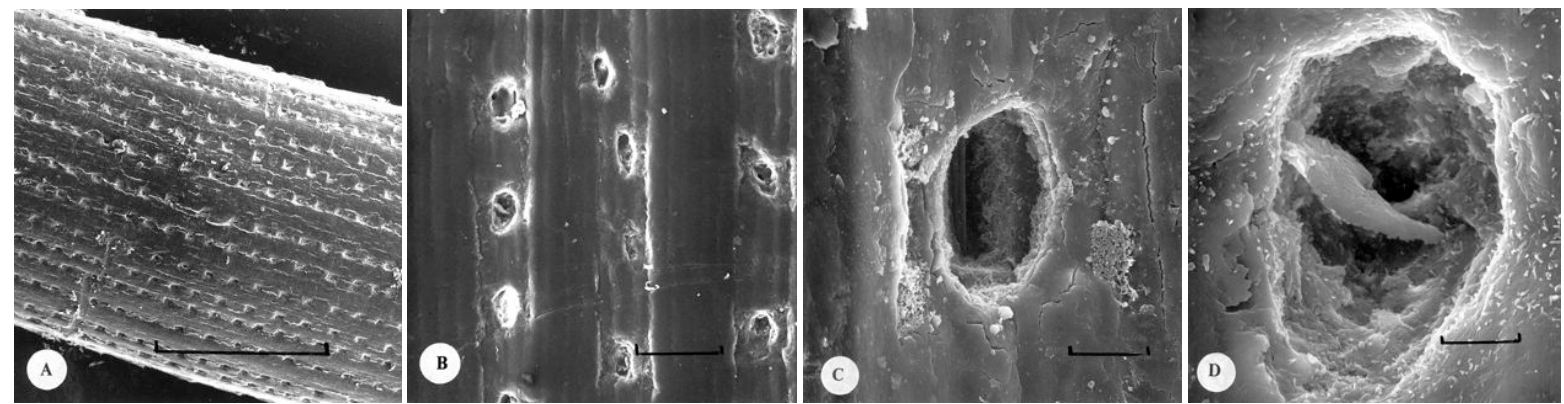

Figure 2. Pinus coulteri overview of the needle (A); The stomatal rows with and without wax plugs (B); Stomata without wax plugs ((C) and (D)). Riverside botanic gardens and San Bernardino Mountains, 1985, 1986. Bars (A) and (B) $=10 \mu \mathrm{m}$, (C) and (D) $=1 \mu \mathrm{m}$.


Figure 3. Pinus albicaulis (site 5) overview of the young needle (A); and stomata with wax plug (B); P. monophylla (site 10) overview of the young needle (C); and stomata with eroded epistomatal waxes of two-year-old needle (D). Bar (A) and (B) = $10 \mu \mathrm{m},(\mathrm{C})$ and $(\mathrm{D})=1 \mu \mathrm{m}$.
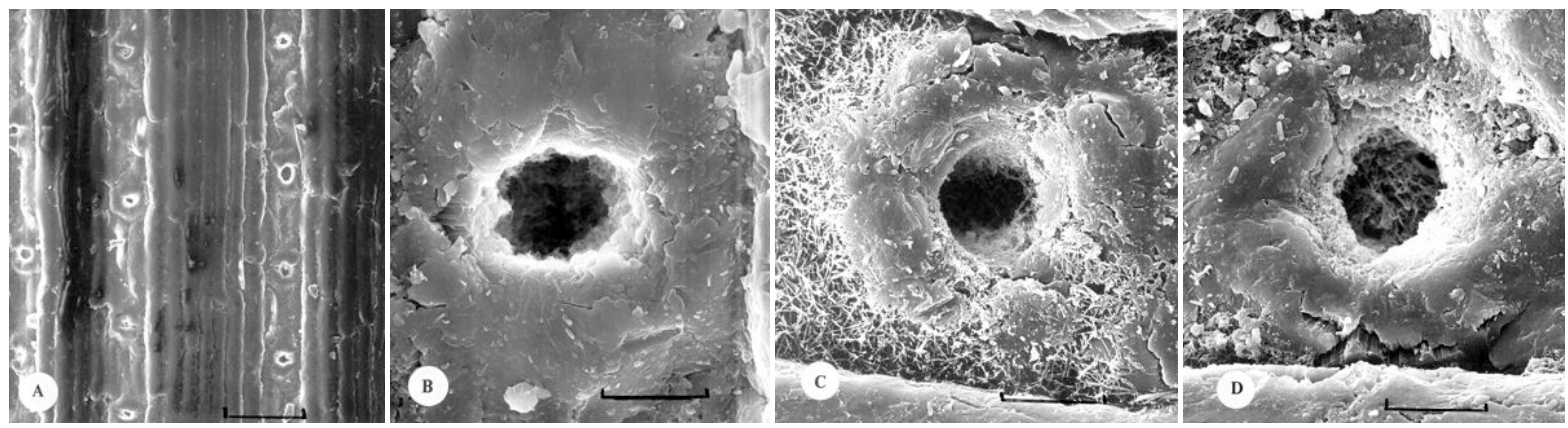

Figure 4. Pinus jeffreyi (site 8) overview of epicuticular waxes and stomata: needles of 1985 in March 1986 (A); Same needle stoma without wax plug. Needles with open stomata of 1985 in March 1986 (B); Needles of 1984 in March 1986 (C); Needles of 1983 in March 1986 (D). Bars (A) $=10 \mu \mathrm{m},(B)=1 \mu \mathrm{m}$.

P. monophylla trees indicated chlorotic mottling at one site but not at the other. Samples typically featured erosion of epistomatal waxes, which was more abundant at the higher elevation site $(2650 \mathrm{~m})$ (Figure 3(C), Figure 3(D), Table 4). 

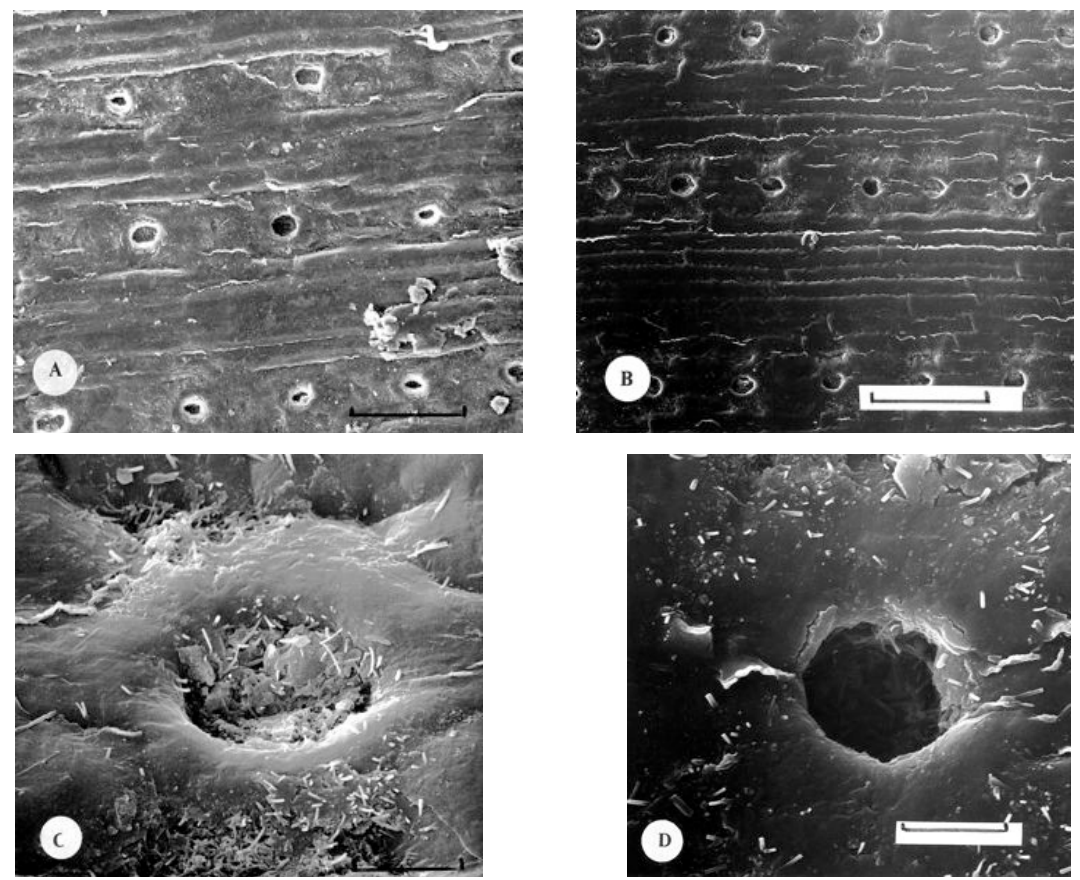

Figure 5. Pinus ponderosa ((A), (B)). An overview of stomatal rows, needles of 1984 in March 1985 ((A), site 7; (B), site 5). Young needles of Pinus ponderosa (site 5) in 1986 (C). Needle year 1984 in 1986 (D). Bar (A) and (B) $=10 \mu \mathrm{m},(C)$ and (D) $=1 \mu \mathrm{m}$.

\subsubsection{6}

In 2006, the same trees were sampled (no samples $P$. attenuata and $P$. muricata). Only three of the needle samples collected were found to be without mottling symptoms; these were $P$. coulteri one year old needles from the Botanic Garden and P. monophylla both one and two-year-old needles (from the same site as earlier with healthy needles). We micrographed needle epistomatal and epicuticular waxes with special emphasis on stomatal wax plugs. In four species $P$. coulteri, $P$. jeffreyi, $P$. monophylla and $P$. ponderosa, stomata with or without wax plugs were found both on adaxial and abaxial surfaces of needles. The lack of epistomatal wax plugs was evident in all species with mottling symptoms (Figure 6).

Pinuslambertiana Dougl. (sugar pine) was an additional species studied in 2006. Whang et al. [24] consider the wax surface well-developed and stomatal wax plugs to be present in this species. In our study, the stomatal waxes were well-developed and plugs were present. The high ridges of needle surface affected the wax diagnostics (results not shown).

The overall condition of the cuticular surfaces of the four species studied previously had improved when compared with samples collected in 1985 and 1986. This may be as a result of the improved air quality in the area [25] (Figure 7). However, visible mottling symptoms were common in all species (Table 3), and differences between needle age classes revealed a characteristic erosion of epicuticular waxes. Stomatal wax plugs were abundant, but stomata without wax plugs were found in all species.

Controlled exposure studies and field studies of $\mathrm{O}_{3}$ impacts on Western conifer species have demonstrated chlorotic mottle as typical visible $\mathrm{O}_{3}$ injury, which begins as a degradation of mesophyll cells below the epidermis [26]. This mesophyll degradation is mainly caused by acute $\mathrm{O}_{3}$ responses [5] [6], and the lack of epistomatal wax plugs seem to be associated with chronic effects, e.g. changes in water holding capacity and gas exchange of needles.

In our study, we measured several epicuticular wax parameters in order to be able to connect observations with existing mottling and tip burn injuries. The variation of cuticle micromorphology in different pine species makes inter-species comparisons difficult, but response comparisons between sites in the same species have an indicative and diagnostic value.

The microscopic diagnosis for specified $\mathrm{O}_{3}$-induced symptoms in the foliage of pine and spruce species is 

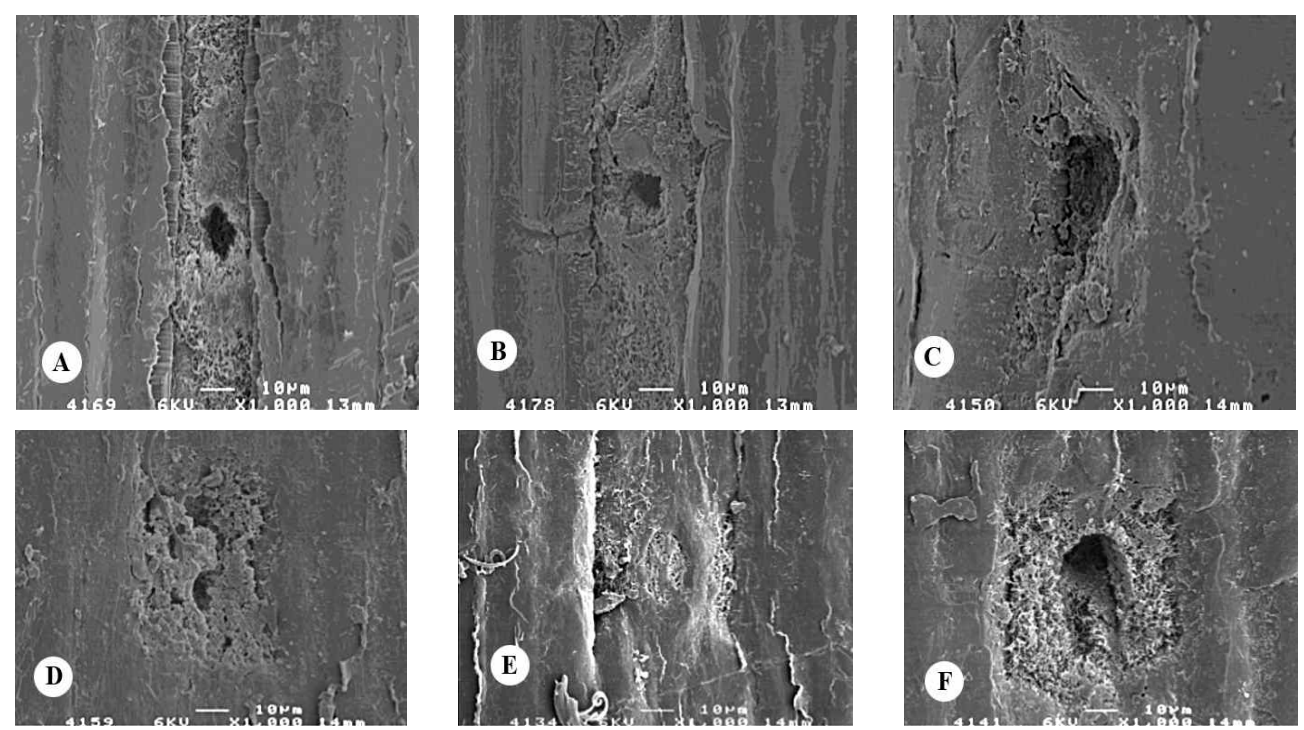

Figure 6. Stomata with or without wax plugs in $P$. jeffreyi ((A), (B)), P. coulteri ((C), (D)) and $P$. ponderosa ((E), (F)) in San Bernardino Mountains in 2006. Overall appearance of epicuticular and epistomatal waxes is clean (compared with 1985 and 1986 samples) without special injuries or particles on surfaces. Note: the micrographs have been taken with different scanning electron microscope.

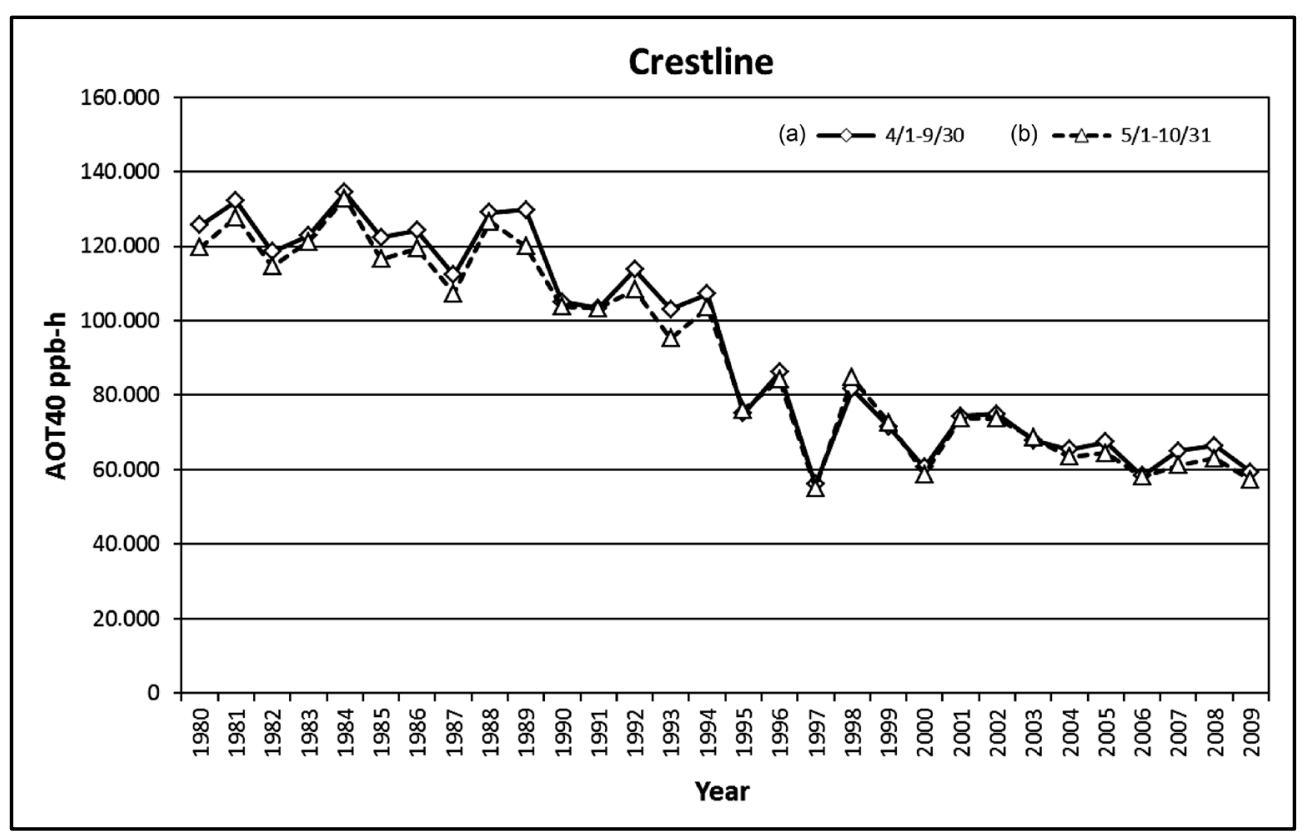

Figure 7. Ozone AOT 40 indices (ppb h) measured at the Crestline site, high exposed to air pollution location in the San Bernardino Mountains 1980-2010. These indices were calculated for two 6-month periods of the growing season: (a) April 1-September 30, and (b) May 1-October 31. A critical level of $\mathrm{O}_{3}$ (a dose above which $\mathrm{O}_{3}$-type damage on trees may develop) has been proposed as $10,000 \mathrm{ppb}$ h [41].

mainly attributed to changes in needle mesophyll cells and their chloroplasts [27]-[29]. In experimental studies, the $\mathrm{O}_{3}$ damage to epicuticular waxes and stomatal responses have either been related to number of stomata per needle, wax synthesis in young developing needles, needle ontogeny or wax amount [30] [31]. Smoothening (mild erosion) of cuticular wax due to $\mathrm{O}_{3}$ exposure has been observed on P. coulteri [32]. Bytnerowicz and Turunen [18] found occluded stomata in young needles of the $\mathrm{O}_{3}$-fumigated $P$. ponderosa, and $\mathrm{O}_{3}$-induced erosion of Piceaabies (Norway spruce) needle wax has also been documented [33]. Due to variability in assessment 
methods, and seasonal versus environmental variability, cuticular and stomatal responses have been considered only of limited importance as environmental diagnostic tools [34]. However, plant-atmosphere interactions are of ultimate importance in understanding long-term air pollution and environmental phenomena effects. The cuticle micromorphology is even useful in indicating past environmental conditions [35]. The role of stomatal wax plugs in conifer-atmosphere interactions, in particular, should also be better understood. In pine needles, an assumption of seasonal existence of winter-time wax plugs, has long been held [36]. In cold climates, the erosion of epicuticular wax and epistomatal wax plugs is evident in situ [37].

Seedlings are used in fumigation experiments, due to seasonal and tree size limitations, and thus needle responses are measured mostly in current-year young needles. In these studies, the observations of stomatal wax plugs and epicuticular waxes have shown only minor injuries [32]. However, under field conditions, $\mathrm{O}_{3}$ injuries in pines are detected in older needles [31] and are chronic. The observed changes related to chronic injuries and aging of needles as well as the role of wax plugs in stomatal conductance and gas exchange during whole needle retention time should be better understood. Currently in California, the physiological basis of $\mathrm{O}_{3}$ injury assessment in conifers uses chlorotic mottle and needle retention [34], but characteristics of needle early injury development are not included.

Evans and Miller [5] [6] emphasized that there was no association between the $\mathrm{O}_{3}$ injury observed, and changes in substomatal needle tissues of the non-fumigated and $\mathrm{O}_{3}$-fumigated needles of $P$. ponderosa, $P$. jeffreyi, $P$. coulteri and $P$. lambertiana. However, their micrographs indicate a lack of wax plugs in $P$. ponderosa and $P$. coulteri. According to Whang et al. [24] stomatal wax plugs should be present in P. ponderosa, P. coulteri, and $P$. lambertiana, but not in $P$. jeffreyi. In our study, wax plugs were present in all these species. Wax plugs were abundant in one-year-old needles, but lacking in the stomata of many needles with chlorotic mottling. Stomatal wax plugs were less abundant in two-year-old needles, which may indicate more advanced mottling, or some aging phenomena [16].

In our study, the high elevation (2800 m) P. jeffreyi had stomata without wax plugs in older needles, but wax plugs were present in younger needles as previously noted [32]. In our study, the individual of $P$. jeffreyi was sampled three times and the observations of symptoms remained the same in all three sampling years. In 2006, chlorotic mottle and stomata without wax plugs were still observed in young needles in April (see Figure 6).

\section{Conclusions}

The lack of stomatal antechamber wax plugs and visible chlorotic mottle symptoms seem to be connected. Recently, Vollenweider et al. [29] showed that presence of cells of mottles is a hypersensitive response of Pinus ponderosa to ambient $\mathrm{O}_{3}$. Whether the lack of wax plugs is a consequence of disturbances in early stomatal development, as found in acid rain-affected needles [37] or a later symptom of dysfunctions, remains unanswered. However, more abundant lack of wax plugs in older needles indicates their late development. The stomata without protective waxes are non-functional. This is also a factor that can predispose pines to specialized fungal diseases [38]), or to a water deficit.

The diagnostic knowledge of stomatal microstructures with or without injuries of different pine species helps to understand the $\mathrm{O}_{3}$ sensitivity of tree species. However, of the main parameters determining whole-tree $\mathrm{O}_{3}$ sensitivity, is stomatal conductance controlling effective $\mathrm{O}_{3}$ uptake [39].

\section{Acknowledgements}

The authors wish to thank Ms Hannele-Heikkilä Tuomaala, Thule Institute for editing the micrographs and Susan Schilling for $\mathrm{O}_{3}$ indices calculations and production of Figure 7. Sally Ulich reviewed the language.

\section{References}

[1] Woodman, J.N. (1987) Pollution-Induced Injury in North American Forests: Facts and Suspicions. Tree Physiology, 3, 1-15. http://dx.doi.org/10.1093/treephys/3.1.1

[2] Miller, P.R., Arbaugh, M.J. and Temple, P.J. (1997) Ozone and Its Known and Potential Effects on Forests in Western United States. In: Sandermann, H., Wellburn, A.R. and Heath, R.L., Eds., Forest Decline and Ozone. Ecological Studies, 127, 39-67. http://dx.doi.org/10.1007/978-3-642-59233-1_2

[3] Miller, P.R. and Evans, L.S. (1974) Histopathology of Oxidant Injury and Winter Fleck Injury on Needles of Western Pine. Phytopathology, 64, 801-806. http://dx.doi.org/10.1094/Phyto-64-801 
[4] Olson, R.K., Binkley, D. and Böhm, M., Eds. (1992) The Response of Western Forests to Air Pollution. Ecological Studies, Vol. 97, Springer Verlag, 532 p.

[5] Evans, L.S. and Miller, P.R. (1972) Comparative Needle Anatomy and Relative Ozone Sensitivity of Four Pine Species. Canadian Journal of Botany, 50, 1067-1071. http://dx.doi.org/10.1139/b72-131

[6] Evans, L.S. and Miller, P.R. (1972) Ozone Damage to Ponderosa Pine: A Histological and Histochemical Appraisal. American Journal of Botany, 59, 297-304. http://dx.doi.org/10.2307/2441432

[7] Evans, L.S. and Miller, P.R. (1975) Histological Comparison of Single and Additive $\mathrm{O}_{3}$ and $\mathrm{SO}_{2}$ Injuries to Elongating Ponderosa Pine Needles. American Journal of Botany, 62, 416-421. http://dx.doi.org/10.2307/2442096

[8] Hetherington, A.M. and Woodward, F.I. (2003) The Role of Stomata in Sensing and Driving Environmental Change. Nature, 424, 901-908. http://dx.doi.org/10.1038/nature01843

[9] Jeffree, C.E., Johnson, R.P.C. and Jarvis, P.E. (1971) Epicuticular Wax in the Stomatal Antechamber of Sitka Spruce and Its Effects on the Diffusion of Water Vapour and Carbon Dioxide. Planta, 98, 1-10. http://dx.doi.org/10.1007/BF00387018

[10] Jeffree, C.E. (2006) Structure and Ontogeny of Plant Cuticles. In: Kerstiens, G., Ed., Plant Cuticles, Bios Scientific Publishers, 33-82. http://dx.doi.org/10.1002/9780470988718.ch2

[11] Yoshie, F. and Sakai, A. (1985) Types of Florin Rings, Distributional Patterns of Epicuticular Wax, and Their Relationships in the Genus Pinus. Canadian Journal of Botany, 63, 2150-2156. http://dx.doi.org/10.1139/b85-304

[12] Schmitt, V.U., Ruetze, M. and Liese, W. (1987) Rasterelektonenmikroskopische Untersuchungen an Stomata von Fichten-Und Tannennadelnnach Begasung und saurer Beregnung. European Journal of Forest Pathology, 17, 118-124. http://dx.doi.org/10.1111/j.1439-0329.1987.tb00736.x

[13] Brodribb, T. and Hill, R.S. (1997) Imbricacy and Stomatal Wax Plugs Reduce Maximum Leaf Conductance in Southern Hemisphere Conifers. Australian Journal of Botany, 45, 657-668. http://dx.doi.org/10.1071/BT96060

[14] Mohammadian, M.A., Watling, J.R. and Hill, R.S. (2007) Do Waxy Stomatal Plugs Impact Leaf Gas Exchange in a Rain Forest Gymnosperm Agathisrobusta. General and Applied Plant Physiology, 33, 203-220.

[15] Turunen, M. and Huttunen, S. (1990) A Review of the Response of Epicuticular Wax of Conifer Needles to Air Pollution. Journal of Environmental Quality, 19, 35-45. http://dx.doi.org/10.2134/jeq1990.00472425001900010003x

[16] Huttunen, S. (1994) Effects of Air Pollutants on Epicuticular Wax Structure. In: Percy, K.E., Cape, J.N., Jagels, R. and Simpson, C.J., Eds., Air Pollutants and Leaf Cuticle, NATO ASI Series, Springer, Berlin, 81-96. http://dx.doi.org/10.1007/978-3-642-79081-2_6

[17] Karhu, M. and Huttunen, S. (1986) Erosion Effects of Air Pollution on Needle Surfaces. Water, Air, and Soil Pollution, 31, 417-423. http://dx.doi.org/10.1007/BF00630859

[18] Bytnerowicz, A. and Turunen, M. (1994) Effects of Ozone Exposures on Epicuticular Wax of Ponderosa Pine Needles. In: Percy, K.E., Cape, J.N., Jagels, R. and Simpson, C.J., Eds., Air Pollutants and Leaf Cuticle, NATO ASI Series G: Ecological Sciences, Vol. 36, Springer, Berlin, 305-314. http://dx.doi.org/10.1007/978-3-642-79081-2_27

[19] Grulke, N.E. (2003) The Physiological Basis of Ozone Injury Assessment Attributes in Sierran Conifers. In: Bytnerowicz, A., Arbaugh, M.J. and Alonso, R., Eds., Ozone Air Pollution in the Sierra Nevada: Distribution and Effects on Forests, Developments in Environmental Science, Vol. 2, Elsevier, Amsterdam, 55-81. http://dx.doi.org/10.1016/S1474-8177(02)02003-X

[20] Paoletti, E. and Grulke, N.E. (2010) Ozone Exposure and Stomatal Sluggishness in Different Plant Physiognomic Classes. Environmental Pollution, 158, 2664-2671.

[21] Richards, B.L., Taylor, O.C. and Edmunds Jr., G.F. (1968) Ozone Needle Mottle of Pine in Southern California. Journal of the Air Pollution Control Association, 18, 73-77. http://dx.doi.org/10.1080/00022470.1968.10469097

[22] Fowells, H.A. (1965) Silvics of Forest Trees of the United States. Agriculture Handbook 271, US Department of Agriculture, Washington DC, $762 \mathrm{p}$.

[23] Price, R.A., Liston, A. and Strauss, S.H. (1998) Phylogeny and Systematics of Pinus. In: Richardson, D.M., Ed., Ecology and Biogeography of Pinus, Cambridge University Press, Cambridge, 49-68.

[24] Whang, S.S., Kim, K. and Hill, R.S. (2004) Cuticle Micromorphology of Leaves of Pinus (Pinaceae) from North America. Botanical Journal of Linnean Society, 144, 303-320. http://dx.doi.org/10.1111/j.1095-8339.2003.00245.x

[25] Bytnerowicz, A., Arbaugh, M., Schilling, S., Fraczek, W. and Alexsander, D. (2008) Ozone Distribution and Phytotoxic Potential in Mixed Conifer Forests of San Bernardino Mountains, Southern California. Environmental Pollution, 155, 398-408. http://dx.doi.org/10.1016/j.envpol.2008.01.046

[26] Stolte, K.W., Duriscoe, D.M., Cook, E.R. and Cline, S.P. (1992) Methods of Assessing Responses of Trees, Stands and Ecosystems to Air Pollution. In: Olson, R.K., Binkey, D. and Böhm, M., Eds., The Responses of Western Forests to Air Pollution, Ecological Studies, Vol. 97, Springer, New York, 259-330. 
http://dx.doi.org/10.1007/978-1-4612-2960-5_8

[27] Kivimäenpää, M., Selldén, G. and Sutinen, S. (2005) Ozone-Induced Changes in the Chloroplast Structure of Conifer Needles, and Their Use in Ozone Diagnostics. Environmental Pollution, 137, 466-475. http://dx.doi.org/10.1016/j.envpol.2005.01.033

[28] Sutinen, S. and Kivimäenpää, M. (2007) The Use of Light Microscopy to Assess the Impact of Ozone Stress on Norway Spruce Needles in the Field. In: Merilä, P., Kilponen, T. and Derome, J., Eds., Forest Condition Monitoring in Finland, National Report 2002-2005, Working Papers of the Finnish Forest Research Institute 45, 120-127.

[29] Vollenwieder, P., Fenn, M.E., Menard, T., Gunthardt-Goerg, M. and Bytnerowicz, A. (2012) Structural Injury Underlying Mottling in Ponderosa Pine Needle Exposed to Ambient Ozone Concentrations in San Bernardino Mountains near Los Angeles, California. Trees, 27, 895-911.

[30] Huttunen, S. and Manninen, S. (2005) Scots Pine and the Changing Environment-Needle Responses. Polish Botanical Studies, 19, 133-141.

[31] Manninen, S., Huttunen, S., Tommervik, H., Hole, L.R. and Solberg, S. (2009) Northern Plants and Ozone. AMBIO, 38, 406-413. http://dx.doi.org/10.1579/0044-7447-38.8.406

[32] Bytnerowicz, A., Olszyk, D.M., Huttunen, S. and Takemoto, B.K. (1989) Effects of Photochemical Smog on Growth, Injury, and Gas Exchange of Pine Seedlings. Canadian Journal of Botany, 67, 2175-2181. http://dx.doi.org/10.1139/b89-276

[33] Barnes, J.D., Davison, A.W. and Booth, T.A. (1988) Ozone Accelerates Structural Degradation of Epicuticular Wax on Norway Spruce Needles. New Phytologist, 110, 309-318. http://dx.doi.org/10.1111/j.1469-8137.1988.tb00267.x

[34] Bermadinger-Stabentheiner, E. (1994) Problems in Interpreting Effects of Air Pollutants on Spruce Epicuticular Waxes. In: Percy, K.E., Cape, J.N., Jagels, R. and Simpson, C.J., Eds., Air Pollutants and the Leaf Cuticle, NATO ASI Series, Vol. 36, Springer, Berlin, 321-327. http://dx.doi.org/10.1007/978-3-642-79081-2_29

[35] Antonello, B. (2011) The Cuticle Micromorphology of Extant and Fossil Plants as Indicator of Environmental Conditions. These de Doctoral en Paleonevironnements et Evolution. Universite Claude Bernard Lyon 1, Lyon, 155 p.

[36] Arneth, A., Loyd, J., Shibistova, O., Sogachev, A. and Kolle, O. (2006) Spring in the Boreal Environment: Observations on Pre- and Post-Melt Energy Fluxes in Two Central Siberian Ecosystems. Boreal Environmental Research, 11, 311-328.

[37] Huttunen, S. and Laine, K. (1983) Effects of Air-Borne Pollutants on the Surface Wax Structure of Pinus sylvestris Needles. Annales Botanici Fennici, 20, 79-86.

[38] Deckert, R.J., Melville, L.H. and Peterson, L.R. (2001) Epistomatal Chambers in the Needles of Pinusstrobus L. (Eastern White Pine) Function as Microhabitat for Specialized Fungi. International Journal of Plant Sciences, 162, 181-189. http://dx.doi.org/10.1086/317905

[39] Matyssek, R., Wieser, G., Calfapietra, C., de Vries, W., Dizengremel, P., Ernst, D., Jolivet, Y., Mikkelsen, T.N., Mohren, G.M.J., Le Thiec, D., Tuovinen, J.P., Weatherall, A. and Paoletti, E. (2012) Forests under Climate Change and Air Pollution: Gaps in Understanding and Future Directions for Research. Environmental Pollution, 160, 57-65. http://dx.doi.org/10.1016/j.envpol.2011.07.007

[40] Richardson, D.M. and Rundel, P.W. (1998) Ecology and Biogeography of Pinus: An Introduction. In: Richardson, D.M., Ed., Ecology and Biogeography of Pinus, Cambridge University Press, Cambridge, 3-46.

[41] Bull, K. (1996) Workshop Summary. In: Karenlampi, L. and Skarby, L., Eds., Critical Level for Ozone in Europe: Testing and Finalizing the Concepts (UN-ECE Workshop Report), University of Kuopio, Finland, 7-8. 